\title{
POPPING CHARACTERISTICS OF SORGHUM GENOTYPES (Sorghum bicolor (L.) Moench)
}

\author{
Irena Golubinova*, Anelia Katova, Anna Ilieva, Plamen Marinov-Serafimov \\ Institute of Forage Crops, Gen. Vladimir Vazov Str. 89, Pleven 5800, Bulgaria
}

\author{
${ }^{*}$ Corresponding author: \\ Phone: +35964805882 \\ Fax: +35964805881 \\ E-mail address: golubinova@abv.bg
}

\begin{abstract}
Twelve genotypes (varieties, hybrids, mutant and hybrid lines) of sorghum (Sorghum bicolor (L.) Moench) were studied. The objective of the study was to determine the popping performance and to establish the relationships with some biochemical parameters (content of crude proteins, starch, moisture) and grain characteristics (pericarp color, grain width, 1000-grain weight). Popping yield of sorghum grain genotypes was in range $32.0 \%-72.0 \%$. The highest influence on popping yield had 1000-grain weight $(r=0.831)$, starch content $(r=-0.356)$, followed by moisture content $(r=0.212)$ and crude proteins $(r=0.282)$. It was found that the endosperm of the seeds expanded poorly in most genotypes with white coloring of the pericarp (from 33.3 to $90.1 \%$ ), while for those with a dark-colored seed pericarp, the expansion was from $50.0 \%$ to $160.0 \%$. Mutant line $\mathrm{M} 1$ (6282) (dark brown color of the pericarp) and hybrid line 1643 (white color of the pericarp) stood out with relatively better popping characteristics and particle size of popped grains. This study demonstrated one of the qualities of sorghum grain- poppability and opportunities for enrichment of the genetic diversity for the breeding program in this culture.
\end{abstract}

Key words: sorghum (Sorghum bicolor (L.) Moench), breeding, sorghum pops, popping

\section{INTRODUCTION}

Sorghum (Sorghum bicolor (L.) Moench) is the world's fifth major cereal in terms of production. Sorghum is believed to originate in the areas of North Africa, where it is predominantly grown to provide a livelyhood for the local population. Nowadays in industrialized countries and some developing countries, sorghum is known as fodder and technical culture and is grown for grain and green mass, silage, sugar syrup, etc. In Bulgaria, the areas under sorghum were over 66000 ha in 2014, according to data from the Department of Agrostatistics at the Ministry of Agriculture, Food and Forestry (MAFF, 2014). According to these data, Bulgaria is ranked $69^{\text {th }}$ in the world.
Worldwide over the last decades, sorghum was also used for the production of biofuels (Liu and Lin, 2009; Ottman, 2009; Manea et al., 2010). Sorghum, in a number of areas, mainly in Asia and Africa, is used in traditional medicine (Duke and Wain, 1981), as well as in the preparation of unleavened bread and pulp for the production of flour, pops, flakes, or in the brewing industry (Baskaran et al., 1999). Flour from sorghum is used in the production of new healthy gluten-free foods (Baskaran et al., 1999). This application of sorghum raises consumer interest mainly in the US and a number of European countries. In the food industry white grain sorghum is 
used due to unobtrusive color and taste (Parker et al., 1999; Duodu et al., 2001; Kayode et al. 2007). The physicochemical, nutritional and anti-nutritional properties of darker and pigmented varieties were also studied (Saravanabavan et al., 2011).

In response to the constantly changing tastes of the consumers and popping quality of sorghum, over the past decades, sorghum has been used in one of the most important areas of the food industry - socalled fast foods. Puffing and popping are the simplest, inexpensive and quick traditional methods for preparation of readyto-eat snack products (Mishra et al., 2014). For this reason there exist scientific studies that investigate the methods of preparing pops from sorghum (Hoke et al., 2005; Mariotti et al., 2006; Mirza et al., 2014). Many factors influence the popping process: moisture content, chemical composition and morphological characteristics of the grain, as well as the method of popping (Mishra et al., 2014).

An important factor in this respect is the difference between varieties. An important condition in modern breeding programs is to combine yield and popping characterristics of grain sorghum, as well as the coloration of the grain which is important for the appearance and consumers' acceptability of popped sorghum. The need for improvement of existing or newly created sorghum genotypes with improved popping characteristics, as well as the limited studies in Bulgaria on sorghum popping performance, justified the purpose of the present work.

The aim of the present study was to investigate the popping performance of sorghum genotype (Sorghum bicolor (L.) Moench) and relate it with some biochemical and morphological characterristics of the grains.

\section{MATERIAL AND METHODS}

In the experimental field of the Institute of Forage Crops, Pleven, Bulgaria, a comparative study was carried out within the sorghum breeding field program, on Sorghum bicolor (L.) Moench grains of various origins (variety, lines and hybrids) (Table 1).

From each sorghum genotype (Sorghum bicolor (L.) Moench), averaged samples of 500 grams of seeds (manually cleaned from impurities, damaged and broken grains) were prepared to determine some grain characteristics in eight replications (grain width, mm; weight per 1000 seeds, g; moisture, \% (AOAC, 2000) and grain pericarp coloration). Biochemical analyses included the determination of crude proteins by Kjeldahl's classic method and starch by Ewers polarimetric method (Yermakov et al., 1972) and were made in two replications.

The popping quality for all studied genotypes (Table 1) was determined after preliminary wetting of 100 seeds in eight replications by using the following modified expression (Mishra et al., 2014):

Expansion Ratio $=\left(D_{f} \times 100 / D_{i}\right)-100$

where $D_{f}$ - Final diameter of popped sorghum; $D_{i}-$ Initial diameter of pretreated sorghum.

Table 1.

Description of the studied genotypes of sorghum (Sorghum bicolor (L) Moench)

\begin{tabular}{lllc}
\hline No & Genotype & Method & Grain coloration \\
\hline 1 & Maxired & Variety & red \\
2 & Maxibel & Variety & white \\
3 & Verdon & Hybrid & brown \\
4 & BBO & Hybrid line & white \\
5 & M1(6282) & Mutant line & deep brown \\
6 & 1641 & Hybrid line & white \\
7 & 1643 & Hybrid line & white \\
8 & 1651 & Hybrid line & white \\
9 & 1673 & Hybrid line & white with brown spots \\
10 & 16113 & Hybrid line & deep brown \\
11 & 16121 & Hybrid line & red \\
12 & 16122 & Hybrid line & brown \\
\hline
\end{tabular}


The seeds of each sample were moistened by dipping for 1 minute in heated (up to $100{ }^{\circ} \mathrm{C}$ ) distilled water, and then dried (Hamad, 2006). The seeds of samples were popped by the conventional method in a closed hot air vessel (Mishra et al., 2014). Quantitative ratio of popped, partially i.e. semi-popped and unpopped was determined in all genotypes of sorghum.

\section{Statistical analysis}

Relationships between some parameters and characteristics of sorghum grain were examined by Pearson correlation coefficients $(p<0.05)$. Replicates were averaged. Simple correlation coefficient $(r \times 1$, ${ }_{x 2}$ ) was then obtained for all studied indicators relative to one another. The statistical processing of the experimental data was carried out with a Statistica Software Package version 10 (StatSoft, Inc., 2011) by One-way ANOVA. Fisher's Least-Significant-Difference (LSD) test was used at the $p<0.05$ probability level.

\section{RESULTS AND DISCUSSION}

Popping of sorghum grains can be related to differences in chemical (protein, starch, fat, ash, moisture, dry matter, etc.), morphological (size, shape of the grain) and physical properties (glassiness, hardness of the seed coat, etc.) of the seeds (Hamad, 2006; Saravanabavan et al., 2011; Mishra et al., 2014). These properties determine the quality characterristics and poppability of the grains.

There were differences in the grain moisture within the individual genotypes, which ranged from 9.18 to $9.97 \%$, while the crude protein content was between 6.25 and $12.01 \%$ on dry matter (d.m.) (Table 2).

From the data in Tables 1 and 2, it seems that the genotypes with dark pericarp (red to dark brown) had higher crude proteins $f$ $(7.00 \%-12.01 \%)$, whereas those with a brighter coloration from 6.25 to $11.42 \%$. The starch content in the sorghum genotypes varied in a relatively narrow range, from 69.88 to $80.45 \%$. An exception was the mutant line M1 (6282), which starch content was the lowest $(69.9 \%)$ but the crude protein content was the highest $(12.01 \%)$. Negative correlation $(r=-0.448)$ between starch and protein contents in sorghum genotypes was found. Such dependence was also reported in the studies of Bressani and Tuna (1992), Wong et al. (2009) and Mishra et al. (2014).

Figure 1 shows the proportion of popped:semipopped:unpopped grains which is an important parameter to describe the popping quality.

Popping yield or total number of popped sorghum grains (sum of partially popped and fully popped grains) varied greatly, from $32.0 \%$ (hybrid line 1673) to $72.0 \%$ (hybrid line 16113). The number of semipopped grains also varied over a wide range from 8.7 to $50.0 \%$. The observed differences within varieties can be explained by genetic differences, because the comparisons were made under equal conditions.

Table 2.

Main characteristics of the sorghum grains

\begin{tabular}{|c|c|c|c|c|c|}
\hline № & Genotype & $\begin{array}{c}\text { 1000-grain weight } \\
(\mathrm{g})\end{array}$ & $\begin{array}{c}\text { Moisture } \\
(\%)\end{array}$ & $\begin{array}{c}\text { Crude proteins } \\
\text { (\% d.m.) }\end{array}$ & $\begin{array}{c}\text { Starch } \\
(\%)\end{array}$ \\
\hline 1 & Maxired & $29.48^{\text {cd }}$ & $9.91^{\mathrm{g}}$ & $10.92^{g}$ & $78.55^{\mathrm{fg}}$ \\
\hline 2 & Maxibel & $29.07^{\text {cd }}$ & $9.97^{\mathrm{g}}$ & $11.42^{n}$ & $78.27^{\dagger}$ \\
\hline 3 & Verdon & $29.93^{d}$ & $9.18^{a}$ & $10.70^{\mathrm{g}}$ & $76.38^{\mathrm{e}}$ \\
\hline 4 & BBO & $25.79^{b}$ & $9.53^{\mathrm{cd}}$ & $9.05^{\mathrm{e}}$ & $78.01^{\dagger}$ \\
\hline 5 & M1(6282) & $28.46^{c}$ & $9.65^{\mathrm{e}}$ & $12.01^{\prime}$ & $69.88^{a}$ \\
\hline 6 & 1641 & $25.30^{\mathrm{a}}$ & $9.51^{c}$ & $8.13^{d}$ & $75.56^{d}$ \\
\hline 7 & 1643 & $25.35^{a}$ & $9.67^{e_{f}}$ & $6.25^{a}$ & $80.45^{\mathrm{h}}$ \\
\hline 8 & 1651 & $25.44^{\mathrm{b}}$ & $9.61^{\text {de }}$ & $6.62^{b}$ & $79.08^{g}$ \\
\hline 9 & 1673 & $25.97^{\mathrm{b}}$ & $9.66^{\mathrm{e}}$ & $7.90^{d}$ & $80.45^{h}$ \\
\hline 10 & 16113 & $29.32^{\text {cd }}$ & $9.55^{\mathrm{cd}}$ & $10.28^{f}$ & $74.20^{c}$ \\
\hline 11 & 16121 & $24.81^{\mathrm{b}}$ & $9.40^{b}$ & $9.16^{\mathrm{e}}$ & $76.92^{e}$ \\
\hline 12 & 16122 & $29.11^{c d}$ & $9.76^{f}$ & $7.00^{c}$ & $73.62^{b}$ \\
\hline
\end{tabular}




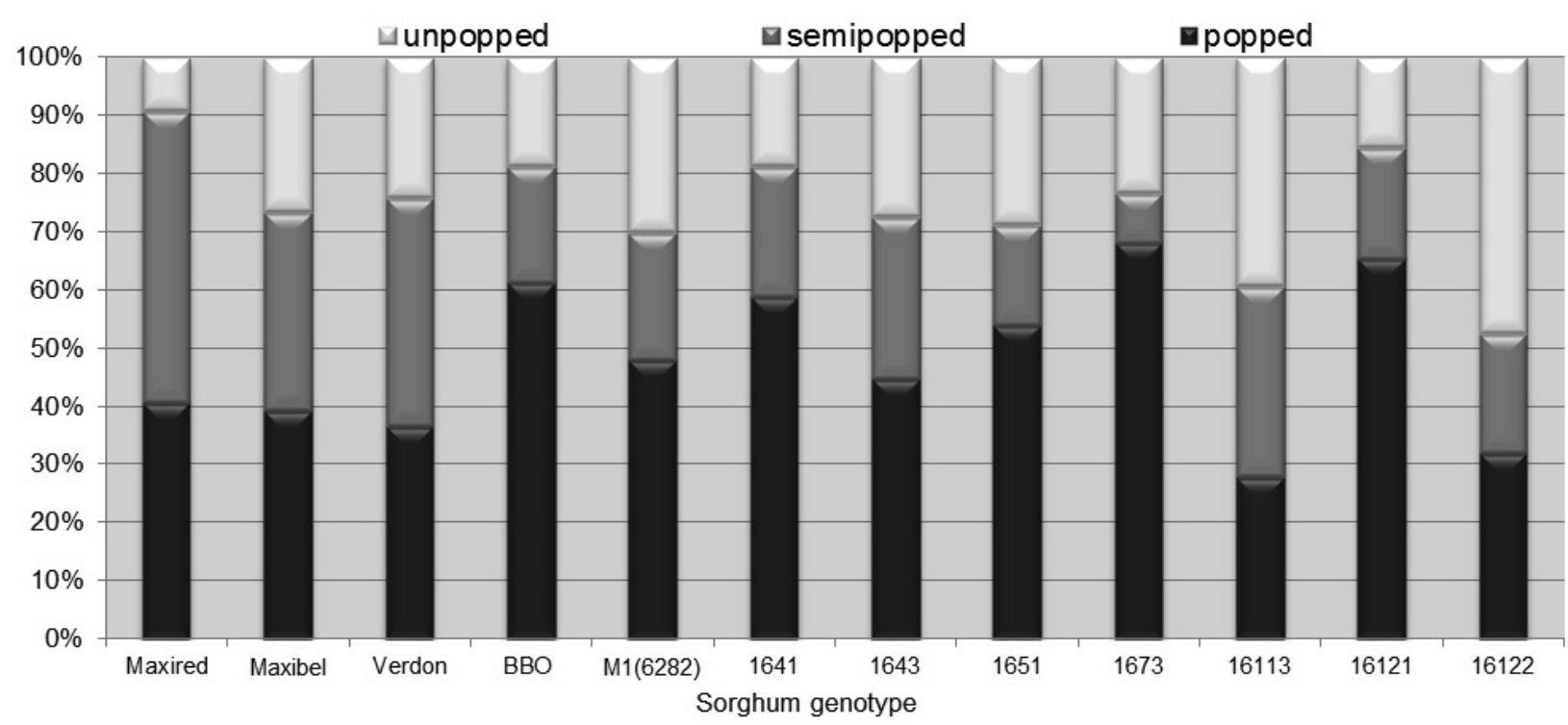

Figure 1. Quantitative ratio of fully popped, partially popped and unpopped grains of the tested sorghum genotypes

Table 3.

Correlations between quality parameters for sorghum genotypes

\begin{tabular}{lcccccc}
\hline Parameters & & 1 & 2 & 3 & 4 & 5 \\
\hline 1000 -grain weight, g & 1 & & & & & \\
Moisture, \% & 2 & 0.214 & & & & \\
Crude proteins, \% & 3 & $0.640^{*}$ & 0.060 & & & \\
Starch, \% & 4 & -0.430 & 0.144 & -0.448 & & \\
Popped grains(total number) & 5 & $0.831^{* *}$ & 0.212 & 0.282 & -0.356 & \\
Diameter of popped grains, mm & 6 & 0.420 & 0.102 & 0.218 & $-0.801^{* *}$ & 0.442 \\
\hline
\end{tabular}

*Significant at the $p=0.05$ level

${ }^{*}$ Significant at the $p=0.01$ level, $(n=8)$

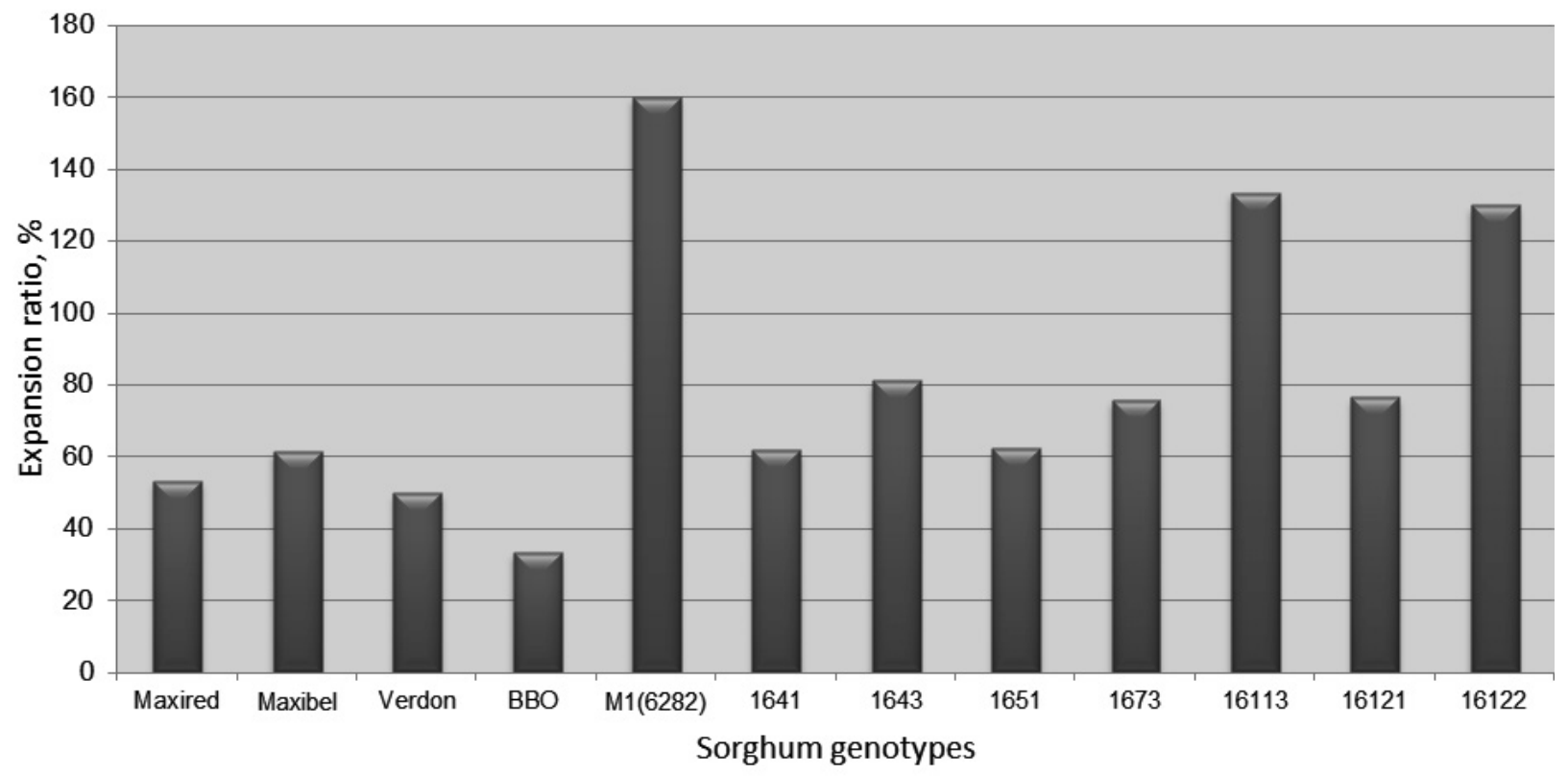

Figure 2. Expansion ratio in popped grains, \%

There was a high correlation between the number of popped sorghum grains and the weight per 1000 seeds $(r=0.831)$, weak with moisture content $(r=0.212)$ and crude proteins $(r=0.282)$ and negative correlation $(r=-0.356)$ with the starch content (Table 3 ). The quantity of sorghum pops was determined by the total number 
of semi-popped and popped grains, as well as by the size of sorghum pops (Figure 2). During popping, the percentage of expansion ratio was the lowest (33.3\%) in the hybrid line BBO and the highest $(160.0 \%)$ in the mutant line M1 (6282) which yielded the biggest sorghum pops.

Larger sorghum pops were found to be derived from genotypes with a higher weight per 1000 seeds $(r=0.420)$ and a lower starch content $(r=-0.801)$. In the dark-colored genotypes (M1 (6282), 16113 and 16122), expansion ratio was the highest (from 130.0 to $160.0 \%$ ), whereas in those with white pericarp expansion the ratio ranged from $33.3 \%$ (BBO hybrid line) to $90.1 \%$ (line 1643) (Figure 3).

The obtained results can be explained with genetic differences among genotypes, as the comparisons were made under the same conditions.

However, under different conditions (other genotypes, grain preparation steps, with presence or absence of grain conditioning, manner and duration of storage of grain, etc.), it can be expected that the results will be different, since popping is determined by a complex of multiple factors.

This study conducted with randomly selected genotypes and breeding materials, focused on the popping properties and performance of sorghum grains. The investigation of grain chemical composition and popping quality are prerequisites for enriching genetic diversity and increasing the efficiency of the sorghum breeding process.

\section{CONCLUSIONS}

Popping yield of the investigated sorghum genotypes ranged from $32.0 \%$ to $72.0 \%$. The strongest influence on the popping yield had the weight of 1000 seeds $(r=$ $0.831)$, the starch content $(r=-0.356)$, followed by moisture content $(r=0.212)$ and crude proteins $(r=0.282)$.

The increase in endosperm during grain popping was the highest in genotypes with white colored pericarp (from 33.3 to $90.1 \%$ ) whereas in those with dark colored pericarp the increase ranged from 50.0 to $160.0 \%$.

Mutant line M1 (6282) (dark brown coloration of the pericarp) and hybrid line 1643 (white coloration of the pericarp) ranked the best with a relatively higher popping yield and larger size of the popped grains. This study demonstrated one of the qualities of sorghum grain and the ability to assist in the course of the breeding process and enrichment of genetic diversity in this culture.

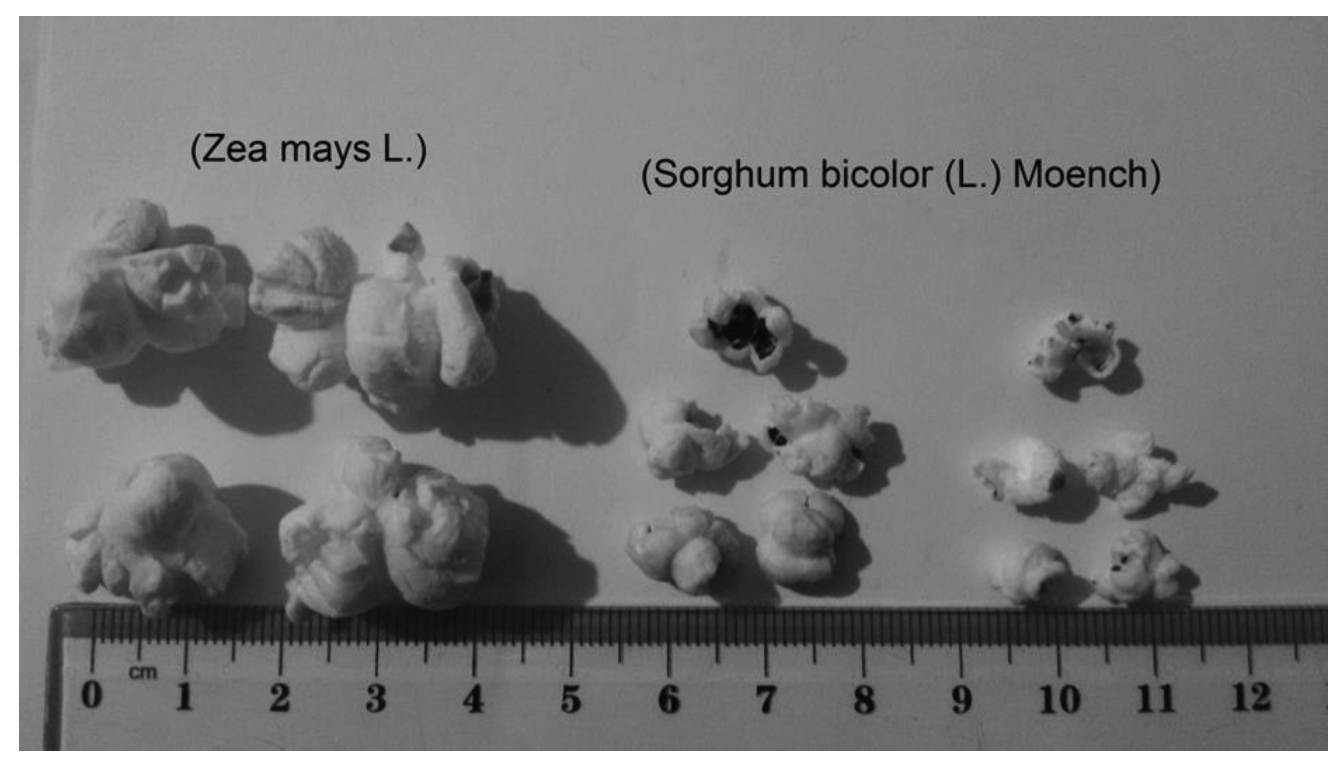

Figure 3. Pops from corn and sorghum (dark and white colored pericarp) 


\section{REFERENCES}

1. AOAC (2010). Official Methods of Analysis, $17^{\text {th }}$ Ed., Association of Official Analytical Chemists, AOAC, International, Maryland, USA.

2. Baskaran, V., Mahadevamma, Malleshi, N.G., Shankara, R., Lokesh, B.R. (1999). Acceptability of supplementary foods based on popped cereals and legumes suitable for rural mothers and children. Plant Foods for Human Nutrition, 53 (3), 237-247.

3. Bressani, R., Tuna, E. (1992). Relation between various physical characteristics of sorghum varieties (Sorghum vulgare) and their popping capacity. Archivos Latinoamericanos De Nutricion, 42 (3), 275-82.

4. Duke, J.A., Wain, K.K. (1981). Medicinal Plants of the World, 3 vol, Plants Genetics and Germoplasm Institute, Agriculture Research Service, Beltsville, Maryland.

5. Duodu, K.G., Tang, H., Gran, A., Weller, N., Belton P.S., Taylor, J.R.N. (2001). FTIR and solid state CNMR spectroscopy of proteins of wet and popped sorghum and maize. Journal of Cereal Science, 33,161-174.

6. Hamad, R.M.E., (2006). Preliminary studies on the popping characteristics of sorghum grains. MSc Thesis, Sudan Academy of Sciences, Al Zaiem Al Azhari University (AAU), Sudan.

7. Hoke, K., Housova, J., Houska, M. (2005). Optimum conditions of rice puffing. Czech Journal of Food Science, 23 (1), 1-11.

8. Kayode, A.P., Linemann, A.R., Nout M., Boekel, M. (2007). Impact of sorghum processing on phytate, phenolics compounds and in vitro solubility of iron and zinc in thick porridges. Journal of the Science of Food and Agriculture, 87, 832-838.

9. Liu, S.Y., Lin, C.Y. (2009). Development and perspective of promising energy plants for bioethanol production in Taiwan. World Renewable Energy Conference, 34 (8), 1902-1907.

10. Manea, V., Tanase, A., Casarica, A., Albulescu, R., Radulescu, G., Campaneu, G., Israel-Roming F., Stoian, G. (2010). Study of the chemical composition of sweet sorghum stalks depleted in carbohydrates with applications in obtaining bioethanol. Analele Ştiinţifice ale Universităţii „Alexandru loan Cuza”, Secţiunea Genetică şi Biologie Moleculară, 9, 87-96.

11. (MAFF) Ministry of Agriculture, Food and Forestry (2014). Production of crops-harvest
2014. Observation of the Agrostatistics Department.

(http://www.sunoilbg.org/language/bg/uploads/fil es/documents 0/document ba9284df81cb1b6 adbf68519b03e0664.pdf).

12. Mariotti, M., Alamprese, C., Pagani, M.A. Lucisano, M. (2006). Effect of puffing on ultrastructure and physical characteristics of cereal grains and flours. Journal of Cereal Science, 43 (1), 4756.

13. Mirza, N., Sharma, N., Srivastava, S., Kuma, A. (2014). Variation in popping quality related to physical, biochemical and nutritional properties of finger millet genotypes. Proceedings of the National Academy of Sciences, India Section B: Biological Sciences, 85 (2), 507-501. doi:10.1007/s400011-014-0384-x.

14. Mishra, G., Joshi, D.C., Panda, B.K. 2014. Popping and puffing of cereal grains: a review. Journal of Grain Processing and Storage, 1 (2), 34-46.

15. Ottman, M. (2009). Annual warm season grasses for biofuel production in the west. Western Alfalfa \& Forage Conference, Reno, Nevada, Proceedings.

16. Parker, M.L., Grant, A., Rigby, N.M., Belton, P.S., Taylor, J.R.N. (1999). Effects of popping on the endosperm cell walls of sorghum and maize. Journal of Cereal Science, 30 (3), 209216.

17. Saravanabavan, S.N., Shivannaq M.M., Bhattacharya, S. (2011). Effect of popping on sorghum starch digestibility and predicted glycemic index. Journal of Food Science and Technology, 50 (2), 387-392.

18. StatSoft, Inc. (2011). STATISTICA (data analysis software system), version 10, Tulsa, OK.

19. Wong, J.H., Lau, T., Cai, N., Singh, J., Pedersen, J.F., Vensel, W.H., Hurkman, W.J., Wilson, J.D., Lemaux, P.G., Buchanan, B.B. (2009). Digestibility of protein and starch from sorghum (Sorghum bicolor) is linked to biochemical and structural features of grain endosperm. Journal of Cereal Science, 49, 73-82.

20. Yermakov, A.I., Arasimovich, V.V., SmirnovaIkonnikova, M.I., Yrosh N.P., Lukovnikova G.A. (1972). Methods of biochemical research of plants, Leningrad, Kolos, p.456. [in Russian] 


\title{
KАРАКТЕРИСТИКЕ КВАЛИТЕТА СИРКА (Sorghum bicolor (L.) Moench) ПРИЛИКОМ ЕКСПАНДИРАЊА (КОКАЊА)
}

\author{
Ирена Голубинова*, Анелиа Катова, Ана Илиева, Пламен Маринов-Серафимов
}

Институт за крмно биље, Ген. Владимир Вазов, 89, 5800 Плевен, Бугарска

Сажетак: У раду је вршено испитивање 12 генотипова (сорти, хибрида, мутаната и хибридних линија) сирка (Sorghum bicolor (L.) Moench). Предмет испитивања је била способност експандирања или кокања зрна сирка и успостављање корелација са осталим квалитетним карактеристикама зрна као што су боја перикарпа, ширина зрна, хектолитарска маса као и одабраних биохемијских својстава (садржај влаге, сирових протеина, скроба и влаге). Принос кокица се кретао у опсегу 32-72\%. Највећи утицај на принос кокица је имала хектолитарска маса $(r=0,831)$, садржај скроба $(r=-0,356)$, садржај влаге $(r=0,212)$ и сирових протеина $(r=0,282)$. Показано је да је експанзија ендосперма зрна била лошија код већине генотипова са белом бојом перикарпа (33,3-90,1\%) док се код генотипова са тамном бојом перикарпа експанзија кретала у опсегу 50-160\%. Мутантна линија М1 (6282) тамне боје перикарпа и хибридна линија 1643 беле боје перикарпа истицале су се релативно бољим својствима приликом кокања и давале су најкрупније кокице. Овај рад даје кратак увид у једно битно својство зрна сиркаспособност кокања (експандирања) које може да се узме у обзир приликом обогаћивања генетске разноликости у програмима селекције сорти ове културе.

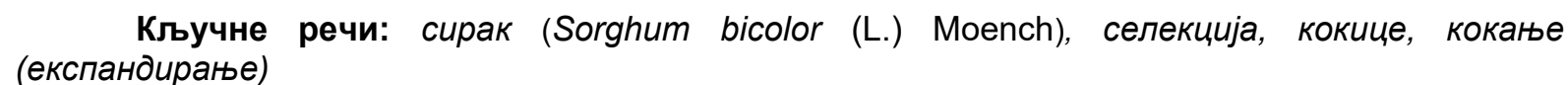

Received: 20 September 2017

Accepted: 9 November 2017 